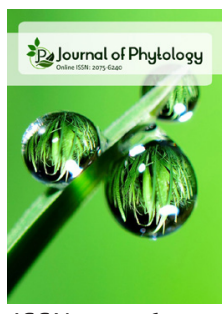

ISSN: $2075-6240$

\title{
Indole-3-acetic acid production by rhizobacteria Bacillus spp. to various abiotic stress factors
}

\section{Piriya Latha Veerasamy², Fitri Ab Aziz Zakry1,3*, Wong Sing King², Susilawati Kasim4, Masnindah Malahubban²}

'Department of Crop Science, Faculty of Agricultural Science and Forestry, Universiti Putra Malaysia Bintulu Campus, 97008 Bintulu, Sarawak, Malaysia, ${ }^{2}$ Department of Animal Science and Fishery, Faculty of Agricultural Science and Forestry, Universiti Putra Malaysia Bintulu Campus, 97008 Bintulu, Sarawak, Malaysia, ${ }^{3}$ Ethnic Borneo Laboratory, Institut Ekosains Borneo, Universiti Putra Malaysia Bintulu Campus, 97008 Bintulu, Sarawak, Malaysia, ${ }^{4}$ Department of Land Management, Faculty of Agriculture, Universiti Putra Malaysia, 43400 UPM Serdang, Selangor, Malaysia
Received: February 20, 2021 Revised: June 16, 2021

Accepted: July 03, 2021 Published: July 15, 2021

\section{*Corresponding Author:} Fitri Ab Aziz Zakry E-mail: zakryfitri@upm.edu.my

\section{Author note:}

This paper is dedicated to the memory of the late Dr. Wong Sing King.

\begin{abstract}
Indole-3-acetic acid (IAA) phytohormone plays an essential role in forming and initiating main, lateral, and adventitious roots in vegetative propagation. Plants are receiving IAA naturally from a diverse group of soil-plant associated rhizobacteria. However, IAA synthesis by rhizobacteria is influenced by abiotic growth condition. Three indigenous Bacillus isolates were subject to in vitro assay for the effects of abiotic factors (temperature, salinity and $\mathrm{pH}$ ) on growth and IAA production. All isolates grew well between $25-40^{\circ} \mathrm{C}$, and only B. megaterium UPMLH3 was capable of synthesising IAA $(21.18 \mu \mathrm{g} / \mathrm{ml})$ at $40^{\circ} \mathrm{C}$. All three bacterial growth under saline stress were slightly dropped over control $(0 \% \mathrm{NaCl})$, but still producing IAA up to $1 \% \mathrm{NaCl}$ condition. B. cereus UPMLH24 revealed high resistance to salinity up to $5 \% \mathrm{NaCl}$. Optimum growth of all three Bacillus spp. was at pH 7. B. cereus UPMLHl and UPMLH24 discovered higher IAA production in slightly alkaline condition ( $\mathrm{pH}$ 8). Each rhizobacterium shows different physiology trait against each abiotic factor. However, the multiple tolerance ability of PGPR against abiotic factors is an indication that its ability to survive under harsh soil and plant environments while delivering benefits to the plant. Thus, B. cereus UPMLH1, B. megaterium UPMLH3 and B. cereus UPMLH24 might serve as potential biofertiliser, enhancing the growth performance of test plants at various environmental conditions.
\end{abstract}

KEYWORDS: Acidity, Bacillus cereus, Bacillus megaterium, Rhizobacteria, Salinity, Temperature

\section{INTRODUCTION}

Plant growth-promoting rhizobacteria (PGPR) enhancing plant growth and yield by direct and indirect mechanisms through increasing nutrients availability, producing phytohormone, and controlling plant diseases (Gouda et al., 2018). Somehow, $80 \%$ of PGPR can synthesise and export phytohormones such as auxins, gibberellins, cytokinins, ethylene and abscisic acid (Kumar et al., 2019). Indole-3-acetic acid (IAA) is a type of auxin involved in the rapid initiation and formation of central, lateral and adventitious roots of plants (Raheem et al., 2018). Several studies clearly showed the effects of various PGPR on the growth of different crops in different climates, soils and temperatures (Fan et al., 2018; Mathes et al., 2020). Among PGPR, genus Bacillus is imperative potential bioinoculants in conventional organic agriculture, as bioenhancer (Probanza et al., 2001; Zakry et al., 2012a), bioregulator (Zakry et al.,
2010; Zakry et al., 2012b) and biocontrol (Domenech et al., 2006; Herman et al., 2008). Other than that, Bacilli are novel rhizobacteria that proficient to adapted and stimulated various type of economic plants; including pine, Pinus sp. (Probanza et al., 2001), oil palm, Elaeis guineensis (Zakry et al., 2012a), black pepper, Piper nigrum (Aziz et al., 2015), tomato, Lycopersicon esculentum (Domenech et al., 2006), rice, Oryza sativa (Thakuria et al., 2004), pigeon pea, Cajanus cajan and wheat, Triticum aestivum (Tilak and Reddy, 2006). Bacilli can survive for prolonged periods in the soil in the form of hardy spores (Paul et al., 2019).

Environmental stresses, including temperature, soil $\mathrm{pH}$, salinity and drought, are among the most limiting factors to plant productivity. Among these, salinity is one of the most unfavourable factors that could limit agriculture's future in most productivity areas of the world (Ashraf, 1994). Environmental 
abiotic factors affect the diversity and biological activity of microorganisms in the soil (Khan et al., 2020). Delivering multiple abiotic stress-resistant PGPR as biofertiliser helps improve the total resistance system of those plants against stress environment while enhancing plant biomass and yield (Banerjee et al., 2010).

In previous studies (Zakry et al., 2010; Zakry et al., 2012b), B. cereus UPMLH1, B. megaterium UPMLH3 and B. cereus UPMLH24 showed different responses to the early development of shallot (Allium ascalonicum) and mustard (Brassica juncea) plants. They have different shallot and mustard development responses with additional IAA production capability. PGPR signals and reactions to plants in the rhizosphere are different between species, variety, and plant vegetative stage. Other than plant-bacteria association, abiotic environmental factors are also involved in manipulating a complex communication system between PGPR and plants in the rhizosphere. Nevertheless, association of IAA bacteria to the IAA pool in the rhizosphere depends on several factors, including population size of IAA synthesising bacteria and amount of IAA produced by an individual cell in rhizosphere. Thus, this study was conducted to assay the tolerance capability of indigenous PGPR Bacillus spp. isolates on IAA production against in-vitro temperature, saline and $\mathrm{pH}$ stress conditions.

\section{MATERIALS AND METHODS}

Strain Bacillus cereus UPMLH1, Bacillus megaterium UPMLH3 and Bacillus cereus UPMLH24 with GenBank/EMBL/DDBJ accession number HQ876003, JN012241, and HQ876004, respectively; used in this study were previously isolated from soil and root samples of pepper vine (Piper nigrum L.) of Kuching and Semengok Emas varieties grown under stress and low soil fertility condition and characterised as indole-3-acetic acid synthesiser (Zakry et al., 2010).

Overnight grown bacterial culture $(1000 \mu \mathrm{L})$ was transfer into $50 \mathrm{~mL}$ of sterile nutrient broth and incubated at different temperatures $\left(25,28,35\right.$ and $\left.40^{\circ} \mathrm{C}\right)$ for $96 \mathrm{~h}$ and shaken at $140 \mathrm{rpm}$. Fully grown bacterial cultures were harvested and centrifuged at $4000 \mathrm{rpm}$ for $20 \mathrm{~min}$. The supernatant $(2 \mathrm{~mL})$ was mixed with $4 \mathrm{~mL}$ of Salkowski reagent $(50 \mathrm{~mL}, 35 \%$ of sulphuric acid, $1 \mathrm{~mL} 0.5 \mathrm{M} \mathrm{FeCl}_{3}$ solution) and kept in the dark for $25 \mathrm{~min}$ as described by Gordon and Weber (1951). The development of the pink colour in the mixture indicates IAA production. Optical density was taken at $530 \mathrm{~nm}$ using a UV-Vis spectrophotometer. Development of pink colour measured at $540 \mathrm{~nm}$, and the IAA production by rhizobacteria estimated based on a standard graph of IAA in the range of $0-100 \mu \mathrm{g} / \mathrm{mL}$. Bacteria were grown in different $\mathrm{NaCl}$ concentrations $[0.1,0.5,1.0$ and $5.0 \%(\mathrm{w} / \mathrm{v})]$ and various $\mathrm{pH}$ (4.0 to 10.0 with 1.0 interval) for $96 \mathrm{~h}$ at $28 \pm 1{ }^{\circ} \mathrm{C}$ and IAA production was quantified as described earlier. All data (except optical density of bacteria cell) subjected to Analysis of Variance (ANOVA). The mean separation was done using the least significant difference (LSD) at $\mathrm{p}<0.05$.

\section{RESULTS}

In general, the growth of all three Bacilli spp. decreased as the incubation temperature increased (Figure 1). Even though
B. cereus UPMLH1 had better growth at $\mathrm{OD}_{530 \mathrm{~nm}}$ of $1.77-1.83$ under $25-40^{\circ} \mathrm{C}$ incubations than B. megaterium UPMLH3 and B. cereus UPMLH24, but the highest growth was achieved at $25^{\circ} \mathrm{C}\left(\mathrm{OD}_{530 \mathrm{~nm}}\right.$ of 1.83$)$. B. cereus UPMLH24 recorded highest growth at $28^{\circ} \mathrm{C}\left(\mathrm{OD}_{530 \mathrm{~nm}}\right.$ of 1.79$)$ and followed by $25^{\circ} \mathrm{C}\left(\mathrm{OD}_{530 \mathrm{~nm}}\right.$ of 1.78). Strain B. cereus UPMLH1 and UPMLH24 synthesised higher IAA at $25^{\circ} \mathrm{C}$ (with $23.97 \mu \mathrm{g} / \mathrm{mL}$ and $28.56 \mu \mathrm{g} / \mathrm{mL}$ ), and no IAA detected under incubation of $40^{\circ} \mathrm{C}$. IAA production by $B$. megaterium increased as the incubation temperature increased from 25 to $35^{\circ} \mathrm{C}$ (with the range of $15.46-27.34 \mu \mathrm{g} / \mathrm{mL}$ ) and sudden fall at $40^{\circ} \mathrm{C}$. However, B. megaterium was the greatest IAA producer among all three strains after $28^{\circ} \mathrm{C}$ of incubation.

In general, all three Bacillus spp. strains have good growth under $0-5 \%$ saline condition, and B. cereus UPMLHl revealed better overall growth (Figure 2). Strain B. megaterium has the same OD (1.78 respectively) with 0 and $1 \%$ saline conditions. Strain B. cereus UPMLH24 has higher growth rate with $0.5 \% \mathrm{NaCl}$ (with OD 1.80) and it followed by $0 \% \mathrm{NaCl}$ (with OD 1.79). On the whole, B. cereus UPMLH24 has higher IAA production than B. cereus UPMLHI and B. megaterium UPMLH3 under $0-5 \%$ saline conditions. IAA production by B. cereus UPMLH24 dropped (from $28.56 \mu \mathrm{g} / \mathrm{mL}$ to $5.14 \mu \mathrm{g} / \mathrm{mL}$ ) as the salinity level increased. However, strain B. megaterium UPMLH3 synthesised higher amount of IAA under $0.5 \%$ saline (with $18.21 \mu \mathrm{g} / \mathrm{mL}$ ) than $0 \% \mathrm{NaCl}$, and no IAA was detected at $5 \%$ saline stress.

All three Bacillus sp. strains were grown at $\mathrm{pH}$ 5-10, and no growth observed at $\mathrm{pH} 4$ (Figure 3 ). B. cereus UPMLH1, B. megaterium UPMLH3 and B. cereus UPMLH24 have tremendous growth at $\mathrm{pH}$ neutral. Strain B. cereus UPMLH1 shown better growth under alkaline conditions ( $\mathrm{pH} 8$-10 with 1.3-1.4 OD). In contrast, strain B. cereus UPMLH24 has good change under slightly acidic conditions ( $\mathrm{pH}$ 5-7). However, $B$. megaterium UPMLH3 revealed almost consistent growth in the range of $\mathrm{pH}$ 5-10 (with OD 1.59-1.70) than other strains. B. cereus UPMLHI has higher production of IAA under slightly acidic ( $\mathrm{pH}$ 6) and alkaline ( $\mathrm{pH} \mathrm{8)} \mathrm{conditions} \mathrm{at} 51.05 \mu \mathrm{g} / \mathrm{mL}$ and $51.94 \mu \mathrm{g} / \mathrm{mL}$, respectively. B. cereus UPMLH 24 produced the highest amount of IAA $(56.66 \mu \mathrm{g} / \mathrm{mL})$ at $\mathrm{pH} 8$.

\section{DISCUSSION}

Landa et al. (2004) documented a slight temperature change, causing remarkable changes in rhizobacterial population and biological activities. This fact helps explain the findings of the present study. The population size of Bacillus spp. strains were inverted to temperature rising. The IAA synthesising activity by B. cereus UPMLHl and UPMLH 24 at $28^{\circ} \mathrm{C}$ was dropped about $72 \%$ and $74 \%$, respectively, from $25^{\circ} \mathrm{C}$ incubation. B. cereus UPMLH1 and UPMLH24 produce IAA at an optimal level at $25^{\circ} \mathrm{C}$. However, strain B. megaterium UPMLH3 has reached a tolerance to high temperature at $40^{\circ} \mathrm{C}$ on IAA synthesising activity, with optimum productivity was reached under $35^{\circ} \mathrm{C}$ condition. This phenomenon indicates that B. cereus and $B$. megaterium have the differential regulation on the structural development of plant roots by producing a variable level of IAA where the IAA production capacity of bacteria probably influenced by fluctuating soil temperature. 


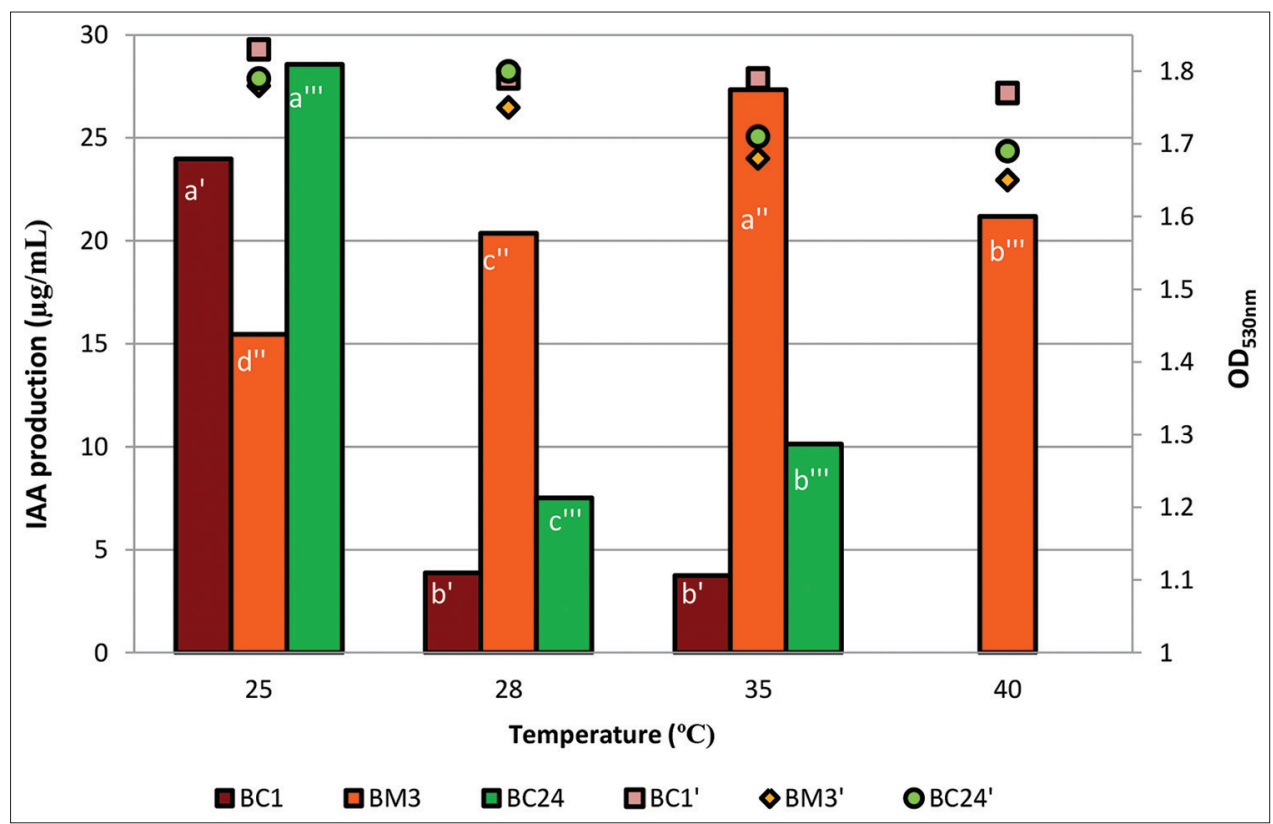

Figure 1: Influence of temperature on growth and IAA production by rhizobacteria

Note: BC1: B. cereus UPMLH1; BM3: B. megaterium UPMLH3; BC24: B. cereus UPMLH24. BC1', BM3' and BC24' represent as OD bacteria cell; Means followed by different letters within single, double and triple primes are significantly different at $p \leq 0.05$

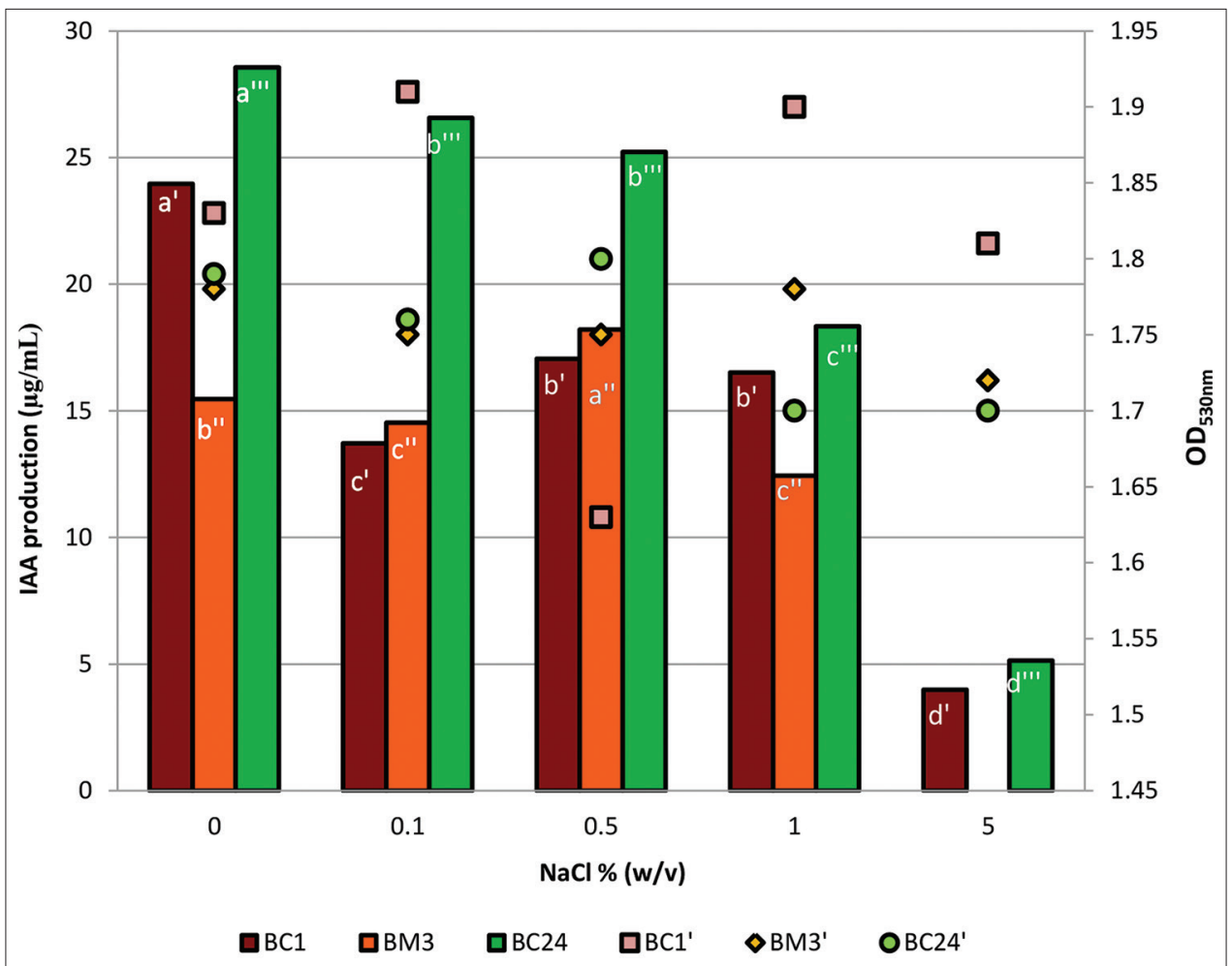

Figure 2: Influence of salinity on growth and IAA production by rhizobacteria

Note: BC1: B. cereus UPMLH1; BM3: B. megaterium UPMLH3; BC24: B. cereus UPMLH24; BC1', BM3' and BC24': OD of bacteria cell; Means followed by different letters within single, double and triple primes are significantly different at $p \leq 0.05$

Even though the population densities of all three strains have fluctuated within a different level of saline conditions, they have high tolerance toward IAA synthesising activity. B. cereus had shown more tolerance to salinity than B. megateriun. This phenomenon may vary due to different physiological trait with peptide antibiotics, peptide signal molecules and extracellular enzymes emissions against unfavourable environmental conditions (Gardener, 2004). Saline tolerance PGPR can inhibit and associate with plant roots at various saline environments and enhance plant health (Lugtenberg \& Kamilova 2009; 


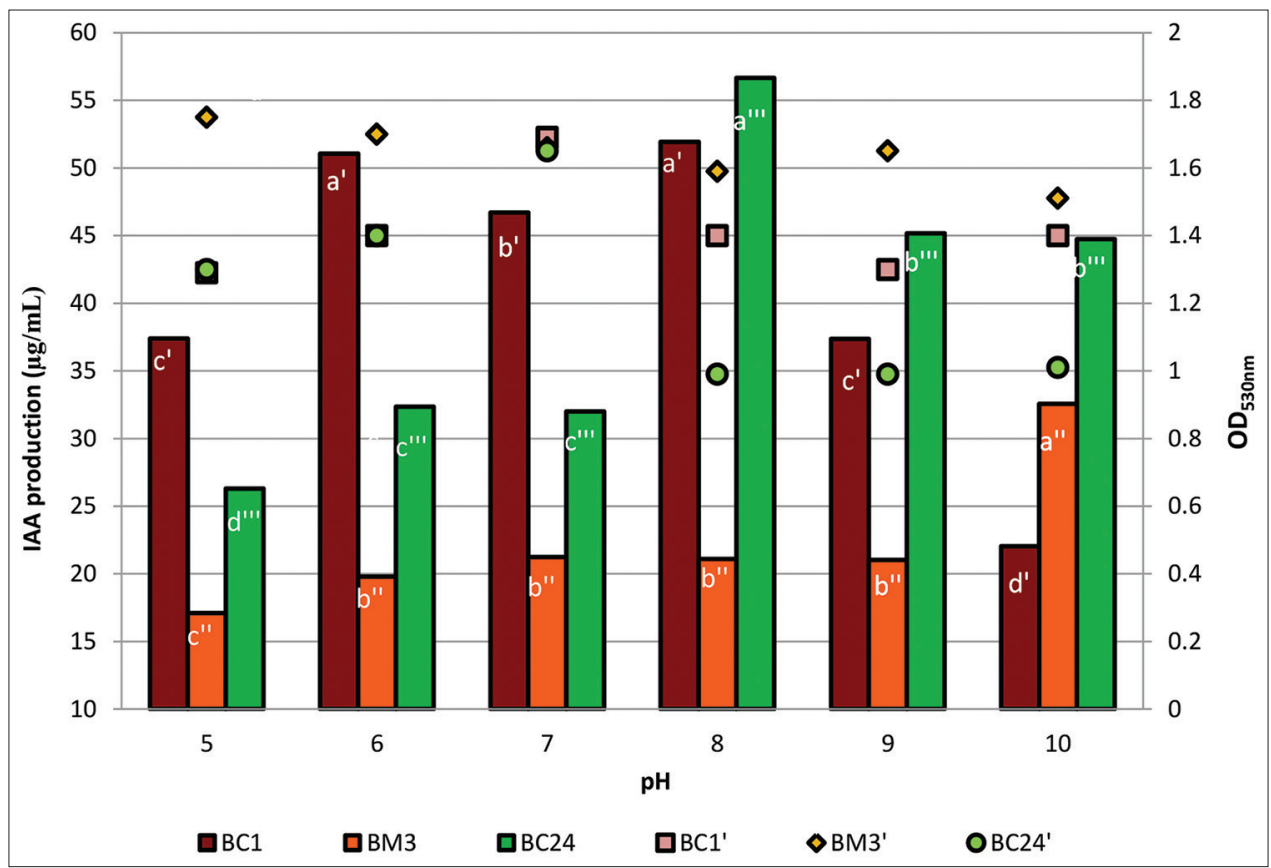

Figure 3: Influence of $\mathrm{pH}$ on growth and IAA production by rhizobacteria Note: BC1: B. cereus UPMLH1; BM3: B. megaterium UPMLH3; BC24: B. cereus UPMLH24; BC1' BM3' and BC24': OD of bacteria cell; Means followed by different letters within single, double and triple primes are significantly different at $p \leq 0.05$

Banerjee et al., 2010). In general, Bacillus species fast evolved in adaptation to various saline environments and improve plant tolerances to ecological stress (Marulanda et al., 2010).

Salinity may directly or indirectly inhibit cell division and the elongation growth of plants. On the other hand, plants in the saline agricultural area gave low yield due to osmotic stress and improper water uptake due to transpiration and inadequate nutrition (Singh \& Chatrath, 2001). Few researchers are working on the growth enhancement of different plants' types by beneficial saline tolerance PGPR inoculants under saline stress to encounter those problems. Those findings show that saline tolerance PGPR improved biomass growth of plants and improved water status, nutrient content, and yield (Kohler et al., 2009). In count with that, saline tolerant IAA producing B. cereus UPMLH1, B. megaterium UPMLH3 and B. cereus UPMLH24 are proficient to improved morphology and physiology of plants roots and modulate plant responses to saline osmotic stress. However, the actual mechanisms between PGPR and plant at the rhizosphere are still unrevealed puzzles in the scientific world.

A pH factor could put up a barrier to microorganisms population and diversity in soil (Brockwell et al., 1991: Palmer \& Young, 2000). Beneduzi et al. (2008b) \& Karagoz et al. (2012) discovered that the most prominent bacteria in different soil types are genera Bacillus and Paenibacillus. All three Bacillus strains successfully managed to grow and produce IAA at various $\mathrm{pH}$ ranges ( $\mathrm{pH} 5-10)$. Each strain showed a different characteristic in this study. Both B. cereus strains in the current study revealed opposite physiological trait at various $\mathrm{pH}$ ranges. Population density of B. cereus UPMLHl more or less retain in both acidic and alkaline conditions, while B. cereus UPMLH24 have drastic dropped at alkaline state, but producing a high amount of IAA. Although the optimum pH for Bacilli is 7 (Ash et al., 1993), pH tolerance can vary among species' strains. These diverse responses with $\mathrm{pH}$ by Bacillus PGPR probably correlated with the complex acidic-alkaline pool composition of root exudates in the plant rhizosphere (Dakora \& Phillips, 2002).

Among abiotic factors, soil acidity is the main factor that directly influences soil microorganisms' diversity and crop growth, development, and yield. Acidic soils with a $\mathrm{pH}$ less than 5.0 usually have a limited amount of available nitrogen, phosphorus, potassium, calcium, magnesium and other micronutrients (Vijila \& Jebaraj, 2008). Improper addition of agrochemical fertiliser to the soil to sustain optimum or high plant yield, however, in the long term it has decreasing the soil fertility by acidifying soil. Several studies clearly showed that the crop inoculated with PGPR enhancing plant growth and yield with the potential to reduce chemical fertiliser application (Naveed et al., 2008; Akbari et al., 2011; Zakry et al., 2012a). IAA producing PGPR with high tolerance to $\mathrm{pH}$ can adapt and inhabit various type of acidic and alkaline soil (Beneduzi et al., 2008a; Beneduzi et al., 2008b: Vijila \& Jebaraj, 2008). Meanwhile, promoting plant growth, PGPR can also improve soil fertility and health (Haskett et al., 2020).

\section{CONCLUSION}

The multiple tolerance ability of PGPR against abiotic factors indicates its ability to survive under harsh soil and plant environments while delivering benefits to the plant. B. cereus UPMLH1, B. megaterium UPMLH3 and B. cereus UPMLH24 have differential responses on IAA-producing capacity to 
abiotic parameters. B. cereus UPMLH24 appears a more promising biofertiliser under saline conditions. This finding may help determine appropriate strategies for the biofertiliser formulation, storage and application.

\section{ACKNOWLEDGEMENTS}

Authors wish to thank Research University Grant Scheme (RUGS) of Universiti Putra Malaysia for financial support, and Universiti Putra Malaysia for overall support.

\section{REFERENCES}

Akbari, P., Ghalavand, A., Sanavy, M. A. M., \& Alikhani, M. A. (2011). The effect of biofertilisers, nitrogen fertiliser and farmyard manure on grain yield and seed quality of sunflower (Helianthus annus L.). Journal of Agricultural Technology, 7(1), 173-184.

Ash, C., Priest F. G., \& Collins, M. D. (1993). Molecular identification of rDNA group 3 Bacilli (Ash, Farrow Wallbanks and Collins) using a PCR probe test. Antonie van Leeuwenhoek, 64, 253-260. https:// doi.org/10.1007/BF00873085

Ashraf, M. (1994). Breeding for salinity tolerance proteins in plants. Critical Review in Plant Science, 13, 17-42. https://doi. org/10.1080/07352689409701906

Aziz, Z. F. A., Halimi, M. S., Kundat, F. R., Jiwan, M., \& Wong, S. K. (2015). Rhizobacterium Bacillus cereus induces root formation of pepper (Piper nigrum L.) stem cuttings. Research in Biotechnology, 6(2), 23-30.

Banerjee, S., Palit, R., Sengupta C., \& Standing, D. (2010). Stress induced phosphate solubilisation by Arthrobacter $\mathrm{sp}$. and Bacillus sp. isolated from tomato rhizosphere. Australian Journal of Crop Science, 4(6), 378-383

Beneduzi, A., Peres, D., da Costa, P. B., Zanettini, M. H. B., \& Passaglia, L. M. P. (2008a). Genetic and phenotypic diversity of plantgrowth promoting bacilli isolated from wheat fields in southern Brazil. Research in Microbiology, 159, 244-250. https://doi.org/10.1016/j. resmic.2008.03.003

Beneduzi, A., Peres, D., Vargas, L. K., \& Bodanese-Zanettini, M. H. (2008b). Evaluation of genetic diversity and plant growth promoting activities of nitrogen-fixing bacilli isolated from rice fields in South Brazil. Applied Microbiology, 39, 311-320. https://doi.org/10.1016/j. apsoil.2008.01.006

Brockwell, J., Pilka A., \& Holliday, R. A. (1991). Soil pH is a major determinant of the numbers of naturally occurring Rhizobium meliloti in non-cultivated soils of New South Wales. Australian Journal of Experimental Agriculture, 31, 211-219. https://doi.org/10.1071/ EA9910211

Dakora, F. D., \& Phillips, D. A. (2002). Root exudates are mediators of mineral acquisition in low-nutrient environments. Plant and Soil, 245, 35-47. https://doi.org/10.1023/A:1020809400075

Domenech, J., Reddy, M. S. Kloepper, J. W., Ramos B., \& GutierrezManero, J. M. (2006). Combined application of the biological product LS213 with Bacillus, Pseudomonas or Chryseobacterium for growth promotion and biological control of soil-borne diseases in pepper and tomato. Biocontrol, 51(2), 245-258. https://doi.org/10.1007/ s10526-005-2940-z

Fan, D., Schwinghamer, T., \& Smith, D. L. (2018). Isolation and diversity of culturable rhizobacteria associated with economically important crops and uncultivated plants in Québec, Canada. Systematic and Applied microbiology, 41(6), 629-640. https://doi.org/10.1016/j. syapm.2018.06.004

Gardener, B. B. M. (2004). Ecology of Bacillus and Paenibacillus spp. in agricultural systems. Symposium: the nature and application of biocontrol microbes: Bacillus spp. Phytopathology, 94, 1252-1258. https://doi.org/10.1094/PHYTO.2004.94.11.1252

Gordon, S. A., \& Weber, R. P. (1951). Colorimetric estimation of indoleacetic acid. Plant Physiology, 26, 192-195. https://doi.org/10.1104/ pp.26.1.192

Gouda, S., Kerry, R. G., Das, G., Paramithiotis, S., Shin, H. S., and Patra, J. K. (2018). Revitalisation of plant growth promoting rhizobacteria for sustainable development in agriculture. Microbiological Research,206, 131-140. https://doi.org/10.1016/j.micres.2017.08.016

Haskett, T. L., Tkacz, A., \& Poole, P. S. (2020). Engineering rhizobacteria for sustainable agriculture. The ISME Journal, 1-16. https://doi. org/10.1038/s41396-020-00835-4

Herman, M. A. B., Nault, B. A., \& Smart, C. D. (2008). Effects of plant growth promoting rhizobacteria on bell pepper production and green peach aphid infestation in New York. Crop Protection, 27, 996-1002. https:// doi.org/10.1016/j.cropro.2007.12.004

Karagoz, K., Ates, F., Karagoz, H., Kotan, R. \& Cakmakci, R. (2012). Characterisation of plant growth-promoting traits of bacteria isolated from the rhizosphere of grapevine grown in alkaline and acidic soils. European Journal of Soil Biology, 50, 144-150. https://doi. org/10.1016/j.ejsobi.2012.01.007

Khan, N., Bano, A., Ali, S., \& Babar, M. A. (2020). Crosstalk amongst phytohormones from planta and PGPR under biotic and abiotic stresses. Plant Growth Regulation, 90(2), 189-203. https://doi. org/10.1007/s10725-020-00571-x

Kohler, J., Hernández, J. A., Caravaca F., \& Roldán, A. (2009). Induction of antioxidant enzymes is involved in the greater effectiveness of a PGPR versus AM fungi with respect to increasing the tolerance of lettuce to severe salt stress. Environmental Experiment of Botany, 65:245-252. https://doi.org/10.1016/j.envexpbot.2008.09.008

Kumar, A., Patel, J. S., Meena, V. S., \& Ramteke, P. W. (2019). Plant growthpromoting rhizobacteria: strategies to improve abiotic stresses under sustainable agriculture. Journal of Plant Nutrition, 42(11-12), 14021415. https://doi.org/10.1080/01904167.2019.1616757

Landa, B. B., Nava-Crtes J. A., \& Jimenez-Diaz, R. M. (2004). Influence of temperature on plant-rhizobacteria interactions related to biocontrol potential for suppression of Fusarium wilt of chickpea. Plant Pathology, 53, 341-352. https://doi.org/10.1111/j.00320862.2004.01008.x

Lugtenberg, B., \& Kamilova, F. (2009). Plant-growth promoting rhizobacteria. Annual Review of Microbiology, 63, 541-556. https://doi.org/10.1146/ annurev.micro.62.081307.162918

Marulanda, A., Azcon, R. Chaumont, F., Ruiz-Lozano, J. M., \& Aroca, R. (2010). Regulation of plasma membrane aquaporins by inoculation with a Bacillus megaterium strain in maize (Zea mays L.) plants under unstressed and salt-stressed conditions. Planta, 232, 533-543. https:// doi.org/10.1007/s00425-010-1196-8

Mathes, F., Murugaraj, P., Bougoure, J., Pham, V. T., Truong, V. K., Seufert, M., Wissemeier, A. H., Mainwaring, D. E., \& Murphy, D. V. (2020). Engineering rhizobacterial community resilience with mannose nanofibril hydrogels towards maintaining grain production under drying climate stress. Soil Biology and Biochemistry, 142, 107715. https://doi.org/10.1016/j.soilbio.2020.107715

Naveed, M., Khalid, M. Jones, D. L. Ahmad R., \& Zahir, Z. A. (2008). Relative efficacy of Pseudomonas spp., containing ACC-deaminase for improving growth and yield of maise (Zea mays L.) in the presence of organic fertiliser. Pakistan journal of Botany, 40(3), 1243-1251.

Palmer, K. M., \& Young, J. P. W. (2000). Higher diversity of Rhizobium leguminosarum biovarviciae populations in arable soils than in grass soils. Applied and Environmental Microbiology, 66, 2445-2450. https://doi.org/10.1128/AEM.66.6.2445-2450.2000

Paul, C., Filippidou, S., Jamil, I., Kooli, W., House, G. L., Estoppey, A., Hayoz, M., Junier, T., Palmieri, F., Wunderlin, T., \& Lehmann, A. (2019). Bacterial spores, from ecology to biotechnology. Advances in Applied Microbiology, 106, 79-111. https://doi.org/10.1016/ bs.aambs.2018.10.002

Probanza, A., Mateos, J. L., Garcia, J. A. L., Ramos, B., de Felipe M. R., \& Gutierrez Manero, F. J. (2001). Effects of inoculation with PGPR Bacillus and Pisolithus tinctorius on Pinus pinea L. growth, bacterial rhizosphere colonisation, and mycorrhizal infection. Microbial Ecology, 41(2), 140-148. https://doi.org/10.1007/s002480000081

Raheem, A., Shaposhnikov, A., Belimov, A. A., Dodd, I. C., \& Ali, B. (2018). Auxin production by rhizobacteria was associated with improved yield of wheat (Triticum aestivum L.) under drought stress. Archives of Agronomy and Soil Science, 64(4), 574-587. https://doi.org/10.10 80/03650340.2017.1362105

Singh, K. N., \& Chatrath, R. (2001). Salinity tolerance. In: Reynolds, M. P., Ortiz-Monasterio, J. I., and McNab, A. (Eds.) Application of physiology in wheat breeding. México D.F., Mexico: International Maize and Wheat Improvement Center (CIMMYT), 101-110.

Thakuria, D., Taleekdar, N. C., Goswami, C., Hazarika, S., Boro, R. C., \& 
Veerasamy et al.

Khan, M. R. (2004). Characterisation and screening of bacteria from rhizosphere of rice grown in acidic soils of Assam. Current Science, 86(7), 978-985.

Tilak, K. V. B., \& Reddy, B. S. (2006). Bacillus cereus and B. circulans- novel inoculants for crops. Current Science, 90(5), 642-644.

Vijila, K., \& Jebaraj, S. (2008). Studies on the improvement of rhizobiumgreen gram (Vigna radita (L.) wilczek) symbiosis in low nutrient, acid stress soils. Legume Research, 31(2), 126 - 129.

Zakry, F. A. A., Halimi, M. S., Abdul, R. K. B., Osumanu, H. A., Wong, S. K., Franklin, R. K., Stephen L. C. T., \& Make, J. (2010). Isolation and plant growth-promoting properties of rhizobacterial diazotrophs from pepper vine (Piper nigrum L.). Malaysian Applied Biology, 39(2), 41-45

Zakry, F. A. A., Halimi, M. S., Khairuddin, A. R., \& Ahmed, O. H. (2012b) Variable responses on early development of shallot (Allium ascalonicum) and mustard (Brassica juncea) plants to Bacillus cereus inoculation. Malaysian Journal of Microbiology, 8(1), 47-50.

Zakry, F. A. A., Shamsuddin, Z. H., Khairuddin, A.R., Zakaria, Z. Z., \& Anuar, A. R. (2012a). Inoculation of Bacillus sphaericus UPMB-10 to young oil palm and measurement of its uptake of fixed nitrogen using the ${ }^{15} \mathrm{~N}$ isotope dilution technique. Microbes and Environments, 27(3), 257-262. https://doi.org/10.1264/jsme2.ME11309 